\title{
Boletellus fennicus, a new species from Finland
}

\author{
HARRI HARMAJA
}

HARMAJA, H. 1999: Boletellus fennicus, a new species from Finland. - Karstenia 39: 37-38. Helsinki. ISSN 0453-3402

\begin{abstract}
The new species Boletellus fennicus Harmaja (Boletales) is described. The species is known from several localities in southern Finland. It has been misidentified as Xerocomus (Boletus) rubellus (Krombh.) Quél. in Finland. Recently the species was, likewise erroneously, thought to represent Boletellus ripariellus (Redeuilh) Redeuilh described from France.
\end{abstract}

Key words: Boletellus, Finland, taxonomy, Xerocomus

Harri Harmaja, Botanical Museum, Finnish Museum of Natural History, P.O. Box 47, FIN-00014 University of Helsinki, Finland

The well-known small red bolete that had passed as Xerocomus (or Boletus) rubellus (Krombh.) Quél. in Finland was recently identified by me (Harmaja 1998) as Boletellus ripariellus (Redeuilh) Redeuilh, described from France (Redeuilh 1997a, 1997b). However, my identification was not made without some hesitation. Now that Dr. Mauri Korhonen of Botanical Museum (Helsinki) has informed me about his discussions on this case with Dr. Guy Redeuilh (France), and I also have re-evaluated some characters, it is clear that the Finnish material is not conspecific with $B$. ripariellus. As this Finnish bolete is not conspecific with any other existing species, either, it is herewith described as a new species, Boletellus fennicus Harmaja.

$B$. fennicus is very closely related to $B$. ripariellus, differing from the latter especially in the following respects: (1) the cracking of the pileus cuticle is somewhat different (irregularly areolate vs. predominantly radiate), (2) the stipe context is yellowish throughout, (3) the spore apex is specialized ("truncate"), (4) the striation of the spore surface is different (according to communication of Dr. Redeuilh), (5) the habitat ecology may differ as B. fennicus occurs under Betula (and often also Alnus) while $B$. ripariellus has been found associated with Quercus and Salix, and (6) B. fennicus apparently possesses a more northern distribution area.

A description of the characters and habitat, illustrations and a list of representative specimens examined of $B$. fennicus, as well as discussion were published in Harmaja (1998, as $B$. ripariellus). For the time being, the species is known from Finland only. It may prove to have a predominantly north-eastern distribution in $\mathrm{Eu}-$ rope.

Boletellus fennicus Harmaja, n. sp.

Illustrations: Harmaja 1998: Figs. 1-4

Boletelli riparielli valde similis sed ab ea praecipue differt carne stipitis omnino flavida sporisque truncatis cum striis dissimilibus. Sporae $10.0-15.0 \times 4.0-6.0 \mu \mathrm{m}$.

Holotypus: Finland. Etelä-Häme. Lammi: Pappilankylä, Biological station of the University of Helsinki, old park, in lawn under e.g. Betula pendula, 9.IX.1968 Harri Harmaja (H). 
Acknowledgements. I am obliged to Dr. Mauri Korhonen for useful communication and help in clarifying the identity of B. fennicus. Mr. Heino Vänskä, Lic. Phil., kindly checked the Latin text.

\section{References}

Harmaja, H. 1998: Boletellus ripariellus, a hitherto misidentified species in Finland. - Karstenia 38: 45-48. Redeuilh, G. 1997a: Xerocomus ripariellus Redeuilh (sp. nov.) (Bolet des bords de mares). - Documents Mycologiques 26(104): 30-31.

Redeuilh, G. 1997b: A propos de Xerocomus (Boletellus) ripariellus in D.M. 103: 30. - Documents Mycologiques 27(106): 54 .

Received on 18 November 1999 